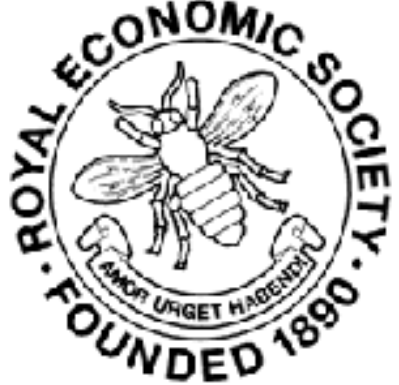

The Economic Legislation for 1903

Author(s): C. A. Montagu Barlow

Source: The Economic Journal, Vol. 14, No. 53 (Mar., 1904), pp. 118-123

Published by: Wiley on behalf of the Royal Economic Society

Stable URL: http://www.jstor.org/stable/2220762

Accessed: 28-02-2015 23:23 UTC

Your use of the JSTOR archive indicates your acceptance of the Terms \& Conditions of Use, available at http://www.jstor.org/page/info/about/policies/terms.jsp

JSTOR is a not-for-profit service that helps scholars, researchers, and students discover, use, and build upon a wide range of content in a trusted digital archive. We use information technology and tools to increase productivity and facilitate new forms of scholarship. For more information about JSTOR, please contact support@jstor.org. 
millinery) to accommodate themselves to the new conditions. This would imply that the Ten-Hours-Day would have to be introduced all over the continent.

The Commission further agreed that dispensations (not exceptions) might be granted in certain cases, agreed on beforehand, of imminent danger to a factory; for example, in cases of fire or explosion, night work would be permitted either to prevent such an accident, or to remedy the damages caused by it. It was also voted that where women worked with perishable products, such as in the fish or fruit industries, night work would be allowable whenever it was absolutely necessary in order to save the produce from complete destruction.

These resolutions were to form part of a memoir to be laid before each Government by the first of March 1904, explaining the whole question of night work for women. As in the case of white phosphorus the Federal Council of the Swiss Confederation was to be asked to initiate an international conference on this subject with a view to an international prohibition of night work for women. Finally, the Commission pointed out the absolute necessity of an inquiry into the question of home industries, more than ever urgently needed, as these very regulations would have the effect of extending their sphere.

Such, in brief, was the work of the meeting at Bâle, which, it is hoped, may lead to an international convention.

E. F.

\section{The Economic Legislation for 1903}

Dealing first with the economic legislation of an Imperial character, we find in the Finance Act (3 Edward VII., c. 8) a reflection of the unsettled fiscal convictions of the times. The duties imposed on various cereals in 1902 are remitted, but those on tea, tobacco, beer, and spirits are retained. The Income Tax is reduced from $1 s$. $3 d$. to $11 d$. By the Revenue Act (3 Edward VII., c. 46), molasses imported for use solely as food for stock is exempted from duty under the Finance Act, 1901 : and in calculating the Inhabited House Duty on houses let in separate tenements, component tenements of a less annual value than $£ 20$ are not assessed, while the rate of duty is reduced to $3 d$. and $6 d$. for those of an annual value between $£ 20$ and $£ 40$, and between $£ 40$ and $£ 60$ respectively. These reductions, how- 
ever, depend, where the annual value is less than $£ 40$, upon the production of a certificate as to the fitness of the accommodation provided and as to the sanitary condition of the dwelling:

As a result of the International Sugar Convention, the Sugar Convention Act (3 Edward VII., c. 21) was passed, giving the Crown power to prohibit by Order in Council the importation of sugar from a country where bounty is granted on the manufacture or export of sugar; and, accordingly, the importation of sugar has been prohibited from Denmark, Russia, and the Argentine Republic. Molasses and sugar-sweetened products are not included in this prohibition.

The total sum granted by the Appropriation Act (3 Edward VII., c. 32 ) was $£ 116,000,000$ as against $£ 151,000,000$ of last year ; the charges for Army services showing a reduction of $£ 35,000,000$. It may be noted that by the Army Act (3 Edward VII., c. 4) an Army of 236,000 men (excluding those in India) is legalised, as against 420,000 in 1902. The appropriations in aid amount to an additional $£ 18,000,000$, of which $£ 5,500,000$ is devoted to meeting the excess of army expenditure for the year 1902-1903.

By the Military Works Act (3 Edward VII., c. 29) an expenditure of $£ 5,000,000$ is authorised on various defence and other works, nearly half of which is appropriated to barracks in South Africa ; and by the Naval Works A.ct (3 Edward VII., c. 22) an expenditure of $£ 8,000,000$ is authorised on various works already (as at Gibraltar and Malta) in progress. This latter sum covers the estimates on these works up to 1905; while, since 1897, a Military Works Act has been passed every second year.

By the South African Loan Act (3 Edward VII., c. 27) the Treasury may guarantee interest not exceeding 3 per cent. on loans raised by the Transvaal for certain purposes. These include $£ 2,000,000$ for compensation to loyalists in Cape Colony and Natal, $£ 14,000,000$ for the acquisition of existing railways, and $£ 15,000,000$ for repatriation, compensation, and development in the Transvaal and Orange River Colony. The total loan that may be guaranteed is $£ 35,000,000$.

Taking next the measures that affect the United Kingdom, the administration of the Patriotic Fund has been placed by the Patriotic Fund Reorganisation Act (3 Edward VII., c. 20), in the hands of a corporation composed (besides nominated members) of all the lord-lieutenants, chairmen of county councils and mayors in the United Kingdom. The fund consists of an invested sum of $£ 1,250,000$, in addition to landed property.

By the Public Works Loans Act (3 Edward VII., c. 28) local 
loans are authorised to be issued by the National Debt Commissioners to the extent of $£ 7,900,000$.

The rapid development of speed in locomotion is evidenced by the Railways (Electrical Power) Act (3 Edward VII., c. 30) and the Motor Car Act (3 Edward VII., c. 36). By the first the Board of Trade is given power to make orders authorising a railway company to make and use electricity, and securing the safety of the public where it is used. By the Motor Car Act the whole use of motor cars is regulated with a view to preventing reckless and dangerous driving and to ensure the readyidentification of offenders. Reckless driving was already an offence both at Common Law and under regulations in connection with the previous Motor Car Act; it is now defined and made an offence under this Act, entailing penalties of $£ 20$ for the first offence, and $£ 50$ or three months' imprisonment for subsequent offences. Drivers are bound to stop when an accident occurs. The maximum rate of speed is enlarged to 20 miles an hour : but the Local Government Board may reduce this to 10 miles an hour within limited areas, and may close special roads to motor cars altogether.

With regard to the increasingly important class of heavy motor cars under 3 tons (which will include the majority of those used in trade), the Local Government Board are empowered to lay down the conditions of their use. A Committee of the Board is at present considering the matter.

The identification of the car is provided for by the compulsory registering of every car with the council of some local authority, and the carrying in a prominent position of the number assigned. The person driving a car on the highway without the number affixed, or with the number obscured, is liable to the penalties before mentioned.

Further control is obtained by the licensing of drivers. These licenses (issued by councils of local authorities), involve no test of the driving powers of the applicant ; but they may be suspended, and the holder disqualified from obtaining another, and it is an offence under the Act to drive a motor car without one. The Act remains in force until 1907.

By the Employment of Children Act (3 Edward VII., c. 45) local authorities are given large powers of regulating the employment of children under 14 by byelaws, to be confirmed by the Secretary of State. They may prohibit employment below a certain age, between certain hours, for more than a certain number of hours per week, or at certain trades. Subject to these byelaws, no child may be employed between 6 p.m. and 9 a.m.; 
and no child shall in any case be employed at an occupation likely to injure his health or education, nor shall any child under eleven trade in the street. Where this Act is contravened, both the employer and the parent of the child become liable to a fine. The power which the Petty Sessional Court had to license the employment of children over seven in public entertainments is now restricted to children over ten.

One Act must be noticed that applies to England and Scotland -the Pistols Act (3 Edward VII., c. 18). Under this Act it is unlawful to sell or hire a pistol to any person who does not produce a gun license or show that he is entitled to carry a gun: unless he is going abroad for six months, or only intends to use the pistol in his own house. It is also unlawful for any person under eighteen years of age to buy or carry a pistol. A penalty of $£ 25$ or three months' imprisonment is placed upon selling a pistol to an intoxicated or insane person.

Among the Acts that apply to England only, the County Courts Act (3 Edward VII., c. 42) extends the jurisdiction of County Courts to claims of the value of $£ 100$ (formerly $£ 50$ ): while the Poor Prisoners' Defence Act (3 Edward VII., c. 38) provides for the assigning to poor prisoners of legal aid in suitable cases at the public expense.

By the Housing of the Working Classes Act (3 Edward VII., c. 39), regulations are made for the re-housing of persons of the working class where land is compulsorily taken. It may be noted that "working class" is defined to comprise mechanics and labourers working for wages: hawkers and others who do not employ anyone but their own family: and persons other than domestic servants whose income does not exceed 30s. a week. Where houses occupied by 30 or more persons of the working class are to be taken, a re-housing scheme shall be approved by the Local Government Board before any house is entered, under a penalty of $£ 500$. The Act also provides that in any letting of a working class house there shall always be an implied condition that it is reasonably fit for human habitation, notwithstanding any agreement to the contrary.

As a result of the indiscriminate use of the streets of London by begging processions, and other collectors of alms, the Metropolitan Streets Act (3 Edward VII., c. 17) enables the police to control by regulation the collection of money in the streets.

The Education Act (1902) is applied to London by the Education (London) Act (3 Edward VII., c. 24). The London 
County Council becomes the local education authority. Their powers (except as to finance) will be exercised by a committee, to which outside experts may be co-opted, and in which at least one woman will be included.

The borough councils will appoint two-thirds of the managers of provided public elementary schools, in their respective areas ; they will also determine (subject to the approval of the Board of Education), the numbers of such managers and how the schools should be grouped. One third of each body of managers must be women. The borough councils must also be consulted in the selection of sites for new public elementary schools: but the Board of Education may, if they think necessary, override their objections.

The managers of non-provided public elementary schools will be appointed as under the Act of 1902-that is to say, four foundation managers to represent the denominational interest, one appointed by the county council, and one by the borough council.

The limit to a $2 d$. rate for higher education imposed by the Act of 1902 will not apply to London. The Act will come into operation on some date before May 1st, 1905, to be appointed by the Board of Education.

With regard to the working of the Education Act, 1902, the Education (Provision of Working Balances) Act (3 Edward VII., c. 10) authorises local education authorities to borrow working balances for carrying the first-named Act into effect.

The Scottish Licensing Laws are revised and consolidated by the Licensing (Scotland) Act (3 Edward VII., c. 25). Part I. of the Act deals with licensing courts and their constitution. Part II. deals with the granting by such courts of certificates to keep inns, etc. Part III. prohibits the granting of excise licenses unless a certificate is first obtained. Part IV. attaches penalties to various offences under the Act. Among other provisions, no person under 16 may be served with spirits to be consumed on the premises; and no person under 14 may be served with excisable liquors to be carried away except in corked and sealed vessels containing not less than one pint; while anyone who sends a child under 14 to fetch excisable liquor (except as above), is liable to a fine. Penalties are also imposed by this Part on riotous behaviour and drunkenness: on procuring drink for a drunken person: and on drinking in an unlicensed house.

Part V. deals with the Registration of Clubs. No excisable liquor may be sold upon the premises of an unregistered club: 
and precautions are taken to ensure the registration of only bona fide clubs. Part VI. deals with legal proceedings.

Another important Scottish Act is the Burgh Police (Scotland) Act (3 Edward VII., c. 33), which amends and enlarges the Burgh Police (Scotland) Act, 1892. It deals with the administration of burghs generally; among other provisions it lays down various rules as to the streets and buildings in a burgh, gives certain additional powers and duties to the burgh authorities, prohibits betting in the streets, and deals with the supply of milk from diseased cows and the manufacture of ice cream.

The Irish Land Act (3 Edward VII., c. 37), which is perhaps the most important measure of the year, and on which the highest hopes are built, cannot be more than touched on here. Its main object is to facilitate and encourage the sale of estates, and the purchase by tenants of their holdings. This is effected either by the purchase of the whole estate by the Land Commission (this only in cases where three-fourths of the tenants agree to purchase their holdings), or by the advance to the tenant of the purchase-money of his holding. The Commissioners may not hold land not agreed to be purchased to the value of more than $£ 5,000,000$.

The tenant will pay off the advance by an annuity of $£ 315 s$. per cent.; this, Mr. Wyndham stated in introducing the Bill, would wipe out the debt in $68 \frac{1}{2}$ years. There are strict provisions against the purchasing tenant sub-dividing, sub-letting, or mortgaging his holding for more than a small amount.

The landlord will be paid in cash, and in addition to the price he will receive a bonus of 12 per cent. from the Treasury. This is to cover the legal expenses (the land system being particularly complicated), and a total expenditure of $£ 12,000,000$ is authorised under this head, for which the Imperial Treasury will get no return.

To raise the cash representing the price of the land, $2 \frac{3}{4}$ per cent. guaranteed stock will be issued by the Treasury. Not more than $£ 5,000,000$ per annum will be issued at first. The total amount required cannot exceed $£ 150,000,000$, and the security for this will be the land in Ireland, and the Imperial contribution to Ireland-which amounts to $£ 2,500,000$ a year. Failing other sources, the interest on the debt will be paid out of this. Only agricultural and pasture land may be dealt with.

\section{A. Montagu Barlow}

